\title{
Reducing the waste and creating the best - sustainable clothes
}

\section{Neerja Gupta}

Received: 04.08.2020; Revised: 06.11.2020; Accepted: 27.11.2020

Author for correspondence :

Neerja Gupta

Department of Philosophy in

Home Science (Textile and

Clothing), Dr Harisingh Gour

Vishwavidyalaya, Sagar (M.P.)

India

Email : neetu18377@gmail.com there is advancement in everything including the types of ABSTRACT : In today's time there is advancement in everything including the types of
clothing materials being made. There has been an overall growth in the world fashion and clothing industry. Due to huge rise in human population there has been an increased demand of clothing which has further lead to an increased amount of waste production. And by human intelligence we are able to create amazing products from even the waste. This paper describes about some of marvels of man which has helped reduce the amount of waste production on this planet.

KEY WORDS: Sustainable Fabric, Eco-Friendly, Fashionable Fabric, Recycled Fabric

- HOW TO CITE THIS PAPER : Gupta, Neerja (2020). Reducing the waste and creating the best sustainable clothes. Asian J. Home Sci., 15 (2) : 348-352, DOI: 10.15740/HAS/AJHS/15.2/348-352. Copyright@ 2020: Hind Agri-Horticultural Society. 